\title{
歯冠の形態修復による咬合治療の予後観察
}

\author{
佐:滕純平中冒真柳村光宽原耕二 \\ 新潟大学歯学部歯科保存学第 2 教室 \\ （主任：原，耕二教授） \\ （昭和 55 年 9 月 17 日受付）
}

\section{A significant aspect of occlusal therapy}

\section{Junpei SATOH, Makoto NAKAJIMA, Mitsuhiro YANAGIMURA and Kohji HARA}

\author{
Department of Periodontology and Endodontics \\ Niigata University School of Dentistry \\ (Chief : Prof. Kohji HARA)
}

Coronal reshaping was done in conjunction with other types of periodontal therapy, such as scaling, curettage and periodontal surgery.

The principal results that have been observed after comprehensive periodontal therapy including coronal reshaping were reduction of the mobility of teeth, change in the position of teeth, improvement in the amount and density of the alveolar bone (radiographically), change in the relation of the mandible or the maxilla, elimination of the bruxism and elimination of pain and improvement in function of the temporomandibular joint.

The reduction in tooth mobility was marked in some cases and resulted in firm teeth with no clinical evidence of mobility. In other cases, but some mobility remained.

The closure of contact between teeth and the movement of teeth into new positions occurred without the use of orthodontic aids.

There was an increase in the height of bone, with filling of the bony defects.

Bruxism is especially destructive in patients with minimal anterior overjet and steep interlocking cusps of the posterior teeth. Coronal reshaping helped to increase the overjet of anterior teeth and to reduce the size of occlusal contacts and the steepness of cuspal inclines of the posterior teeth.

\section{緒論}

歯冠の形態修復とは, 1970 年 $\operatorname{Ross}^{1,2)}$ が提唱した歯 の咀嚼機能を考慮して, 歯面のすべてを修復治療するこ とである。しかし，歯が咬合性外傷を起こしていないと 本論文の要旨は, 昭和 54 年 11 月第 22 回秋季日本歯周病学 会総会において発表した。
きには修復治療を行ってはいけない。適応症に対して は，口腔内で完全に正しく修復を行わなければならない としている。

すでに著者らは，2，3の症例を用いながら歯冠の形 態修復の適応症, 形態修復前の診査, 形態修復に関する 術式, 形態修復を行う際の問題点について 報 告してき $た^{3 \sim 6)}$ 。

そこで今回, 著者らは比較的短期間における, 歯冠の 
形態修復の予後を調査し, その治療効果を検討すること とした。

\section{研究材料と方法}

本研究は, 新潟大学歯学部付属病院保存科飞歯周治療 を目的として来院した患者のうち, 主に学生が臨床実習 に扔いて歯冠の形態修復 (以後咬合調整とする) を行っ た，年齢は 22 歳から 54 歳までの患者 37 名を対象とし た。(男性 14 名, 女性 23 名)。

歯周治療にさきだち, 37 名の患者全員について予め 臨床的ならびに X線学的診查を基に咬合性外傷歯（以後 外傷歯とよぶ）の存在を確認した。歯周治療の内容は, 個々の患者によって異るが, 全体の傾向としては咬合調 整を含めた initial preparation 例が多く、これに菌周 手術を加えた症例が少し含まれる。

予後診查のための資料は, 歯周治療用プロトコール (periodontal chart), 咬合治療用チャート (occlusal chart), スタデーモデル, 全頡用 X線写真を初診時（以 後術前とよぶ）と予後診查時（以後術後とよぶ）飞用意 し,これらを参考に両者の所見を比較検討した。検討事 項は次の 10 項目とした。

（1）年齢別症例数および予後期間

(2) 各歯種の残存歯数と外傷歯数の割合

（3）咬み合わせの変化

(4) 歯の動摇度の変化

(5) 歯槽 (骨) 頂部の変化

(6) 白線の変化

(7) 歯根膜腔の変化

(8) 予後

（9） over bite 変化の有無と予後

(10) 鋭い咬頭斜面の修正の有無と予後

そのうち，(3)の症例は歯ぎしり, 顎関節部の疼痛およ
び機能異常を含み, 術後に行った問診から改善, 不変, 覀化の 3 段階に分類した。(4)はピンセットを使用し, 動 摇度を測定した。0〜2までの 3 段階に分け, 次のよう に判定した。 0 とは正常の場合, 1 とは肉眼的に動摇を 察知しにくいとき指の腹で, 動摇を認知するか，または 肉眼的に唇舌側方向に動摇が認知できる場合， 2 とは唇 舌的, 近遠心的さらには垂直的三方向に動摇が認知でき るほど高度に進んだ場合とに分類した。

(5), (6), (7)の変化は改善, 不変, 悪化の 3 段階に分類 した。(5)で, 改善とは術前, 歯槽（骨）頂部が不明瞭で あったものが, 術後, 明瞭化した場合, 不変とは術前, 術後間で所見に変化がみられなかったもの, 悪化とは術 前, 明瞭であった歯槽 (骨) 頂部が術後, 不明瞭になっ た場合とに分けた。(6)で改善とは術前, 消失していた部 位に術後, 白線の再生がみられた場合, 不変とは術前, 術後間で所見に変化がみられなかった場合，悪化とは術 前にみられた白線が術後, 消失した場合と飞分けた。(7) における改善とは, 術前, 拡大がみられた部位が術後, 正常化した場合, 不変とは術前, 術後間で所見飞変化が みられなかった場合，悪化とは術前，正常であった部位 に術後, 拡大がみられるようになった場合とに分類し た。

(9)の診查は, 上顎前歯を対象歯とし, 術前および術後 時の 2 組のスタデーモデルを参考に行った。(10)は(9)と同 様に 2 組のスタデーモデルを参考に, 目歯部の当該外傷 歯を対象に診査した。

\section{結果}

\section{1）年齢別症例数および予後期間}

表 1 亿示すとおり，37名の対象者は年齢別に 30 歳代 18 名, 40 歳代 12 名となり男女とも 30 歳代, 40 歳代が 多くみられた。咬合調整後の予後期間は, 最短 4 力月か

表 1 年歯別症例数及び歯数

\begin{tabular}{c|cccc|cc}
\hline & $\begin{array}{c}\text { 男 } \\
\text { 症例数 }\end{array}$ & $\begin{array}{c}\text { 女㐘数 } \\
\text { 症例数 }\end{array}$ & $\begin{array}{c}\text { 性 } \\
\text { 㐘数 }\end{array}$ & \multicolumn{2}{|c}{ 症例数 } & 歯数 \\
\hline 20 歳代 & 1 & 6 & 3 & 12 & 4 & 18 \\
30 歳代 & 6 & 17 & 12 & 39 & 18 & 56 \\
40 歳代 & 6 & 30 & 6 & 26 & 12 & 56 \\
50 歳代 & 1 & 3 & 2 & 7 & 3 & 10 \\
\hline 計 & 14 & 56 & 23 & 84 & 37 & 140
\end{tabular}


表 2 残存歯数と外傷歯数の割合

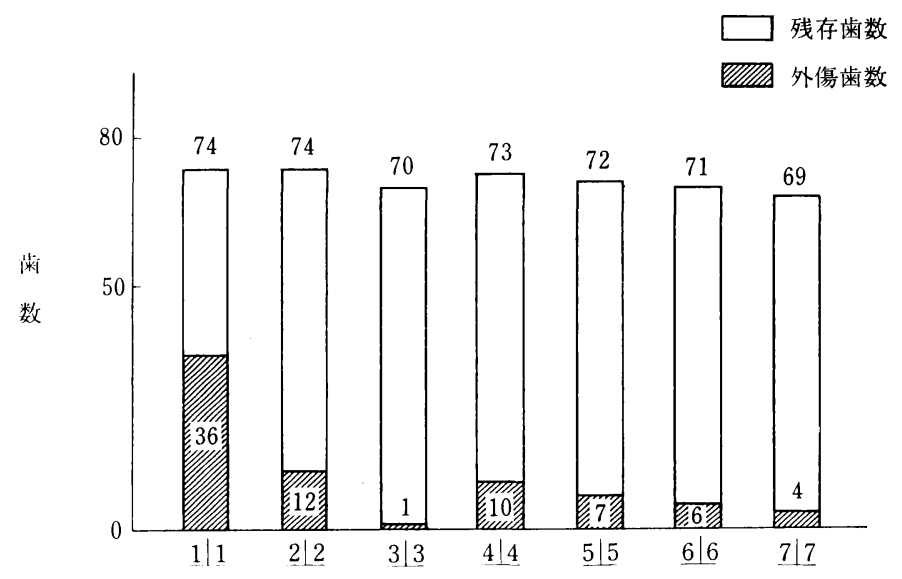

表 3 残存歯数と外傷歯数の割合

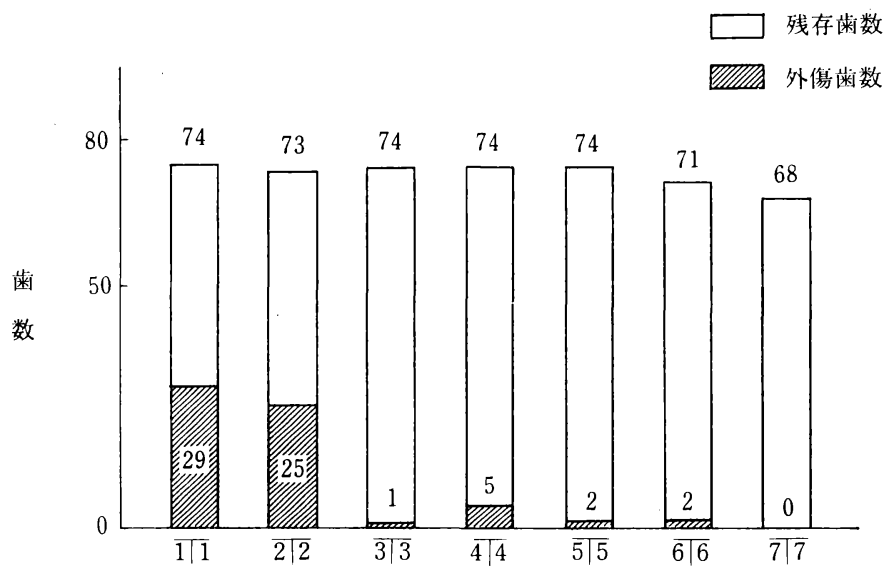

ら最長 1 年 7 カ月までに分布し, 症例の多くは 7 カ月か ら 9 カ月の範囲であった。

\section{2）歯種別残存歯数と外傷歯数の割合}

表 2 , 表 3 亿示すとおり, 対象者 37 名の総歯数は 1,011 歯で, そのうち外傷歯数は 140 歯となり, 外傷歯 の出現率は $13.8 \%$ と判明した。菌種別には $1 \mid 1$ の出現 率が最も高く, 74 歯中 36 歯で $48.6 \%$, ついで $1 \mid 1$ の 74 歯中 29 歯で $39.2 \%$, 最も低かったのは $7 \mid 7$ で 68 歯 中 1 歯もみられなかった。上下顎とも前歯では中切歯, 側切歯にくらべて犬歯での発生率はきわめて低く，上顎 で 70 歯中 1 歯, 下顎は 74 歯中 1 歯であった。また臼歯 では全般的に下顎にくらべ上䫟の方が多発する傾向がみ
表 4 咬合調整後の咬み合わせの変化

（問診による）

\begin{tabular}{c|cc}
\hline 改善 & \multicolumn{2}{|c}{17 名 $(45.9)$} \\
\hline 不変 & 20 & $(54.1)$ \\
\hline 悪化 & 0 & \\
\hline 計 & 37
\end{tabular}

られた。

3）咬み合わせの変化

表 4 亿示したとおり, 37 名の患者のうち, 術前と比 較して咬み合わせが改善したと答えた者が 17 名 45.9 
表 5 咬合調整後の動摇度の変化

\begin{tabular}{|c|c|c|c|}
\hline & 前 歯 & 兒歯 & 計 \\
\hline 改 善 & $(34.6)^{\text {蒌! }}$ & $\begin{array}{c}22^{\mathrm{S}} \\
(61.2)\end{array}$ & $\begin{array}{c}58 \\
(41.5)\end{array}$ \\
\hline 不変 & $\begin{array}{c}67 \\
(64.4)\end{array}$ & $\begin{array}{c}14 \\
(38.8)\end{array}$ & $\begin{array}{c}81 \\
(57.8)\end{array}$ \\
\hline 車化 & $\left(\begin{array}{c}1 \\
1.0\end{array}\right)$ & 0 & $\left(\begin{array}{c}1 \\
0.7\end{array}\right)$ \\
\hline 計 & 104 & 36 & 140 \\
\hline
\end{tabular}

表 6 咬合調整後の歯槽頂の変化

\begin{tabular}{|c|c|c|c|}
\hline & 前 歯 & 臼歯 & 計 \\
\hline 改 善 & $(32.0)^{\text {蕃 }}$ & $\begin{array}{c}12 \\
(35.3)\end{array}$ & $\begin{array}{c}43 \\
(32.8)\end{array}$ \\
\hline 不変 & $\begin{array}{c}66 \\
(68.0)\end{array}$ & $\begin{array}{c}22 \\
(64.7)\end{array}$ & $\begin{array}{c}88 \\
(67.2)\end{array}$ \\
\hline 盓 化 & 0 & 0 & 0 \\
\hline 战 & 97 & 34 & 131 \\
\hline
\end{tabular}

测定不可能 9 釆は除く

\%，変わらないと答えた者は 20 名 $54.1 \%$ で改善率とほ ぼ同率となり，術前より咬み合わせが悪くなったと答え た者は 1 名もみられなかった。興味あることは，37名 の患者のうち, 術前, 歯ぎしりを有する者が 8 名認めら れており，咬合調整後に全員が歯ぎしりの習癖がなくな ったと答えたことである。また, 術前, 顎関節部の疼痛 および機能の異常を有した 3 名の患者のうち, 術後に改 善したと答えた者が 2 名, 変わらないと答えた者が 1 名 認められた。

\section{4）歯の動摇度の変化}

表 5 に示したと㧍り, 前歯 104 歯のうち, 改善 36 料 $34.6 \%$, 不変 67 菊 $64.4 \%$, 悪化 1 歯 $1.0 \%$ の 割 合を示 した。一方， 曰歯は 36 歯中改善 22 歯 $61.2 \%$, 不変 14

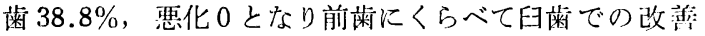
率は高く，雨者の間に佬険率 $5 \%$ 以下で有意差が認めら れた。しかも前歯および目歯ともに術前に動摇の著しい 外傷歯ほどより改善する傾向がみられた。

\section{5）歯槽頂部の変化}

表 6 で示したとおり前歯 97 歯のうち, 改善 31 歯 32.0 $\%$, 不変 66 歯 $68.0 \%$ となり, 臼歯 34 歯 中改善 12 歯
表 7 咬合調整後の白線の変化

\begin{tabular}{|c|c|c|c|}
\hline & 前 歯 & 臼茵 & it \\
\hline 改善 & $(27.9)^{\frac{1}{16}}$ & $\begin{array}{c}4 \\
(11.7)\end{array}$ & $\begin{array}{c}31 \\
(23.7)\end{array}$ \\
\hline 不変 & $\begin{array}{c}69 \\
(71.1)\end{array}$ & $\begin{array}{c}29 \\
(85.4)\end{array}$ & $\begin{array}{c}98 \\
(74.8)\end{array}$ \\
\hline 泪 化 & $\left(\begin{array}{c}1 \\
1.0\end{array}\right)$ & $\left(\begin{array}{c}1 \\
2.9\end{array}\right)$ & $\left(\begin{array}{c}2 \\
1.5\end{array}\right)$ \\
\hline 部 & 97 & 34 & 131 \\
\hline
\end{tabular}

测定不可能 9 桃は除く

表 8 咬合調整後の歯根膜腔の変化

\begin{tabular}{|c|c|c|c|}
\hline & 前㐘 & 臼㐘 & 訫 \\
\hline 改善 & $(7.3)^{7}$ & $\begin{array}{c}3 \\
(8.8)\end{array}$ & $\begin{array}{l}10 \\
(7.6)\end{array}$ \\
\hline 不変 & $\begin{array}{c}87 \\
(89.6)\end{array}$ & $\begin{array}{c}31 \\
(91.2)\end{array}$ & $\begin{array}{l}118 \\
(90.1)\end{array}$ \\
\hline 望化 & $\begin{array}{c}3 \\
(3.1)\end{array}$ & 0 & $\begin{array}{c}3 \\
(2.2)\end{array}$ \\
\hline 計 & 97 & 34 & 131 \\
\hline
\end{tabular}

测分不叮能 9 米は除く

$35.3 \%$, 不変 22 歯 $64.7 \%$ と前歯とほぼ同率 であった。 前歯，臼歯を合わせた全体の改善率は131 歯中 43 歯 の $32.8 \%$, 不変は 131 歯中 88 歯の $67.2 \%$ であった。

\section{6) 白線の変化}

表 7 で示したとおり，前歯 97 歯中改善 27 歯 $27.9 \%$, 不変 69 歯 $71.1 \%$, 悪化 1 歯 $1.0 \%$, 臼歯 34 歯中改善 4 歯 $11.7 \%$, 不変 29 歯 $85.4 \%$ ，悪化 1 歯 $2.9 \%$ であっ た。前歯，且歯を合わせた全体の改善率は 131 洣中 31 歯の $23.7 \%$, 不変は 131 㐘中 98 歯の $74.8 \%$ であった。

\section{7）歯根膜腔の変化}

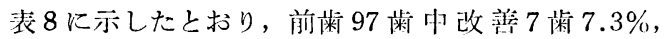

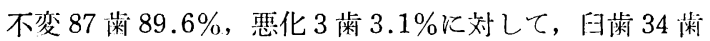
では改善 3 歯 $8.8 \%$, 不変 31 窲 $91.2 \%$, 恶化は 0 であっ た。全体の改善率をみると，131 歯中 10 歯の $7.6 \%$ と洣 槽頂，白線の改善涼にくらべて低い值であった。

\section{8) 予後}

予後の判定を行う際に, 次のような綜合的な判定基準 を定めた：(1) 歯の動摇度の減少を好転, 増加したもの 
表 9 外傷歯の予後

\begin{tabular}{|c|c|c|c|}
\hline & 前j 荗 & 目薾 & 訣 \\
\hline 起 & $(18.5)$ & $\begin{array}{c}9 \\
(26.5)\end{array}$ & $\begin{array}{c}27 \\
(20.6)\end{array}$ \\
\hline やや造好 & $\begin{array}{c}40 \\
(41.2)\end{array}$ & $\begin{array}{c}17 \\
(50.0)\end{array}$ & $\begin{array}{c}5 \% \\
(43.5)\end{array}$ \\
\hline 不 & $\begin{array}{c}34 \\
(35.1)\end{array}$ & $\begin{array}{c}7 \\
(20.6)\end{array}$ & $\begin{array}{c}41 \\
(31.3)\end{array}$ \\
\hline 不 & $\begin{array}{c}5 \\
(5.2)\end{array}$ & $\begin{array}{c}1 \\
(2.9)\end{array}$ & $\begin{array}{c}6 \\
(4.6)\end{array}$ \\
\hline it & 97 & 34 & 131 \\
\hline
\end{tabular}

测定不叮能 9 缕は除く

を悪化，変化なしを不変とする，(2) 歯槽頂の明瞭化を好 転, 希薄化を悪化, 変化なしを不変とする，(3) 白線の再 生がみられたものを好転, 消失を悪化, 变化なしを不変 とする, (4) 歯根膜腔の正常化を好転, 桩大を悪化, 変 化なしを不変とした。予後良好とは(1)の好転および(2)(3) (4)のいずれか 1 つ以上好転が認められたもの, やや良好 とは(1)〜(4)のいずれか $1 つ$ 好転が認められたもの, 不変 とは(1)〜(4)のいずれも変化せず，不良とは (1)〜(4)のら ち，1つでも悪化が認められた場合とした。

以上の判定基準により外傷歯の予後をまとめると, 表 9 のごとく前歯 97 柬のうち良好は 18 歯 18.5\%, やや 主好 40 歯 $41.2 \%$, 不変 34 歯 $35.1 \%$ ，不良 5 歯 $5.2 \%$ を示した。臼歯 34 歯では良好 9 歯 26.5\%, やや良好 17 菌 $50.0 \%$, 不変 7 歯 $20.6 \%$, 不良 1 歯 $2.9 \%$ となり, 前歯, 臼歯間では有意差は認められなかった。前歯, 臼 歯を合わせた全体の改善率は良好 131 歯中 27 歯 20.6 $\%$ ，やや良好 131 歯中 57 歯 43.5\%で両者を合わせると 約 $65 \%$ とかなりの高率を示した。

\section{9） overbite 変化の有無と予後}

表 10 で示したとおり，上顎前菌を対象歯としたもの で，48歯中 overbite の変化のみられなかったものは 32 歯, 変化のあったものは 16 歯であった。変化しなか った 32 歯中予後良好は 3 歯 $9.4 \%$, やや良好は 15 㐘 $46.9 \%$, 不変 14 歯 $43.7 \%$, 不良 0 となり, 変化した 16 菌では予後良好は 3 歯 $18.8 \%$, やや良好 6 歯 $37.4 \%$, 不変 4 歯 $25.0 \%$, 不良 3 㐘 $18.8 \%$ となり, overbite の変化の有無と予後との間に相関性はみられなかった。

10）鋭い咬頭斜面の修正の有無と予後

表 11 に示したとおり，術前鋭い咬頭斜面を有した外
表 10 overbite 変化の有無とその予後

\begin{tabular}{|c|c|c|c|}
\hline & - & + & 計 \\
\hline 等好 & $(9.4)^{3}$ & $\begin{array}{c}3 \\
(18.8)\end{array}$ & $\begin{array}{c}6 \\
(12.5)\end{array}$ \\
\hline やや造好 & $\begin{array}{c}15 \\
(46.9)\end{array}$ & $\begin{array}{c}6 \\
(37.4)\end{array}$ & $\begin{array}{c}21 \\
(43.8)\end{array}$ \\
\hline 不 & $\begin{array}{c}14 \\
(43.7)\end{array}$ & $\begin{array}{c}4 \\
(25.0)\end{array}$ & $\begin{array}{c}18 \\
(37.5)\end{array}$ \\
\hline 不 & 0 & $\begin{array}{c}3 \\
(18.8)\end{array}$ & $\begin{array}{c}3 \\
(6.2)\end{array}$ \\
\hline 計 & 32 & 16 & 48 \\
\hline
\end{tabular}

测定不可能 1 歯を除く

表 11 鋭い咬頭斜面の修正の有無とその予後

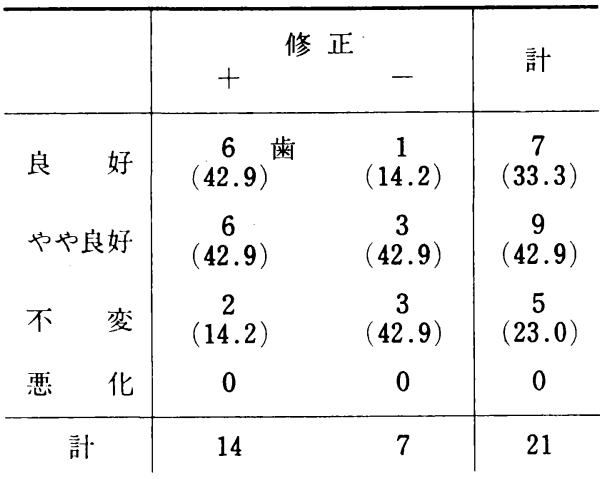

傷罹患且歯 21 歯のうち, 鋭い斜面を修正したものは 14 歯, 修正しなかったもの 7 歯であった。修正 した 14 歯 中予後良好は 6 歯 $42.9 \%$, やや良好 6 歯 $42.9 \%$, 不変 2 歯 $14.2 \%$, 覀化 0 , 修正しなかった 7 歯中予後良好 は1 歯 $14.2 \%$, やや良好 3 歯 $42.9 \%$, 不変 3 歯 42.9 $\%$, 悪化 0 となり, 修正群は非修正群にくらべて予後が より良くなる傾向が認められた。

\section{1）症例報告}

〔症例 1〕 34 歳, 女性, 部位 : $2-F-2$ 咬合性外傷を伴 う歯周炎

術前の所見 : $3-1-3$ にわたり歯肉は腫脹し, 中等度の 炎症と動摇を認める。特に2 2 は挺出をきたし動摇が強 い。 $\overline{2-1-2}$ の切端水平位は不揃いで歯間離開をきたして おり, 唇舌的に叢生を示す。歯周ポケットは $5 \sim 6 \mathrm{~mm}$ と全体的飞深い。上下前歯は前方位及び同滑走, 側方前 方位，同滑走時に不均一な接触と動摇の増加を認める (図 $1-A \sim C$ )。 

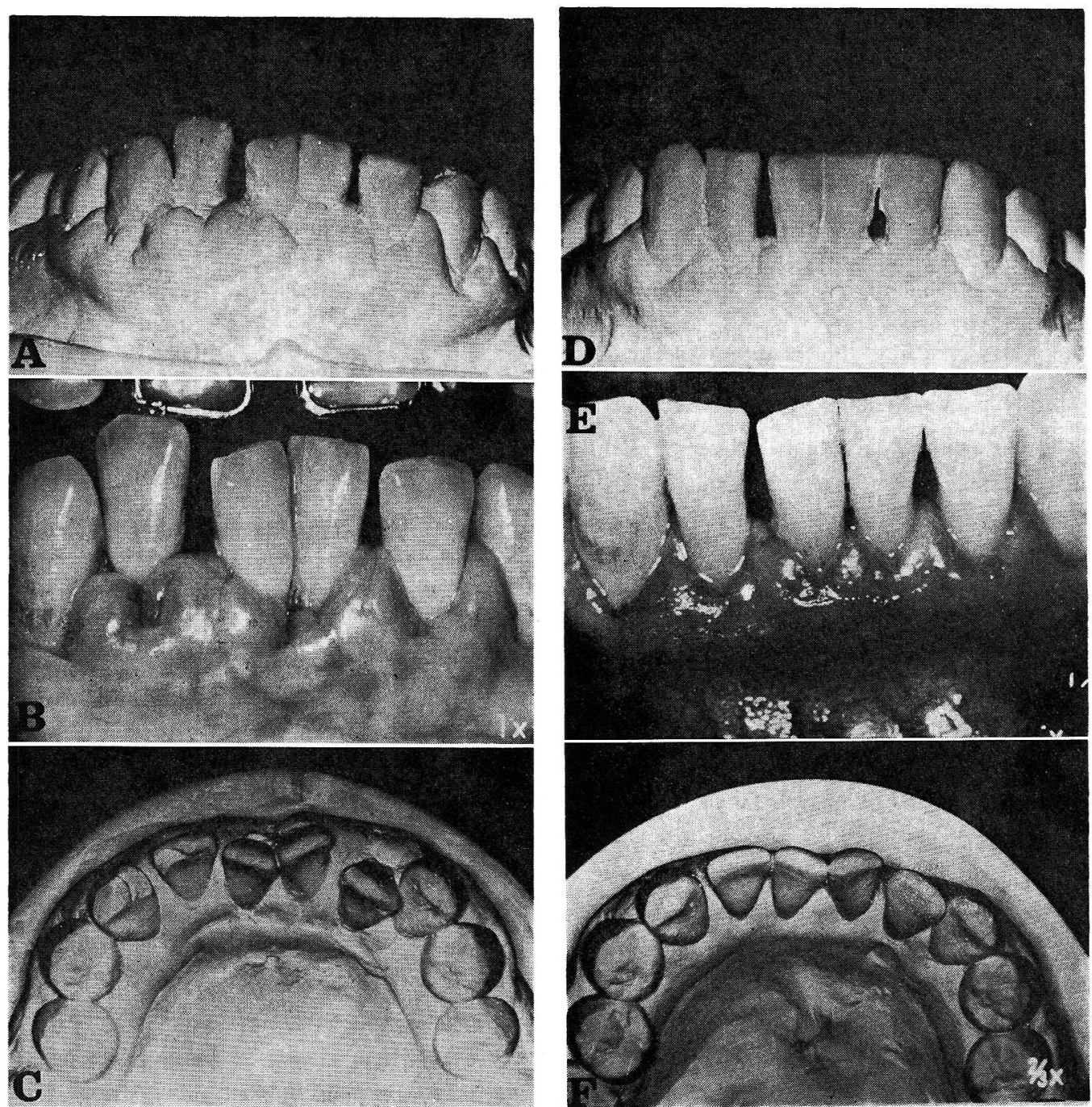

図 1 症例 1

A， B : 2--2 の切端水平位の不扸いと柬間離開を示す

C : 唇舌的叢生を示す

$\mathrm{D}, \mathrm{E}$ : 歯冠の形態修復 3 力月後の所昌. $2--2$ の切端 水平位の改善々歯間離開の閉鎖を示す

F：唇舌的に著しい歯列の改善がみられる

治療経過ならびに予後: $\overline{3-3}$ についてまずフラップ 手術を行い, ついで 1 カ月後に歯冠の形態修復を行っ た。 3 カ月後の診査によると, $2-\mid-2$ の切端水平位レべ ルは改善して矯正装置なしに歯の反応性移動が起こり, 歯閒離開は閉鎖し, 著しい歯列の改善がみられた。歯周 ポケットは消失し, 㐘の動摇は減少して扝り, 経過はき わめて良好といえる（図 1-D〜F）。

〔症例 2] 36 歳, 女性, 部位: $\frac{1}{2--2}$ 咬合性外傷を 伴亏歯周炎
術前の所見：歯肉の炎症は比較的軽度。蒾周ポケット は上顎前歯で $2 \sim 3 \mathrm{~mm}$ と浅いが，下顎前歯は歯閒部で 3〜 $4 \mathrm{~mm}$ とやや哚い。咬合関係はやや overbite で, 下 顎切歯の切端水平位は不揃いで, かつ咬耗も強くみられ る。前方位において特に $\frac{1}{21}$ の接触が強く, 歯の動採は

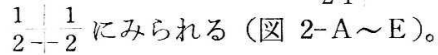

治療経過ならびに予後：まず全顎にわたりプラークコ ントロールと deep scaling を行ったあと, $\frac{2-2}{2-2}$ の歯冠 の形態修復を行った。9 月後の診查によると, 咬合関 

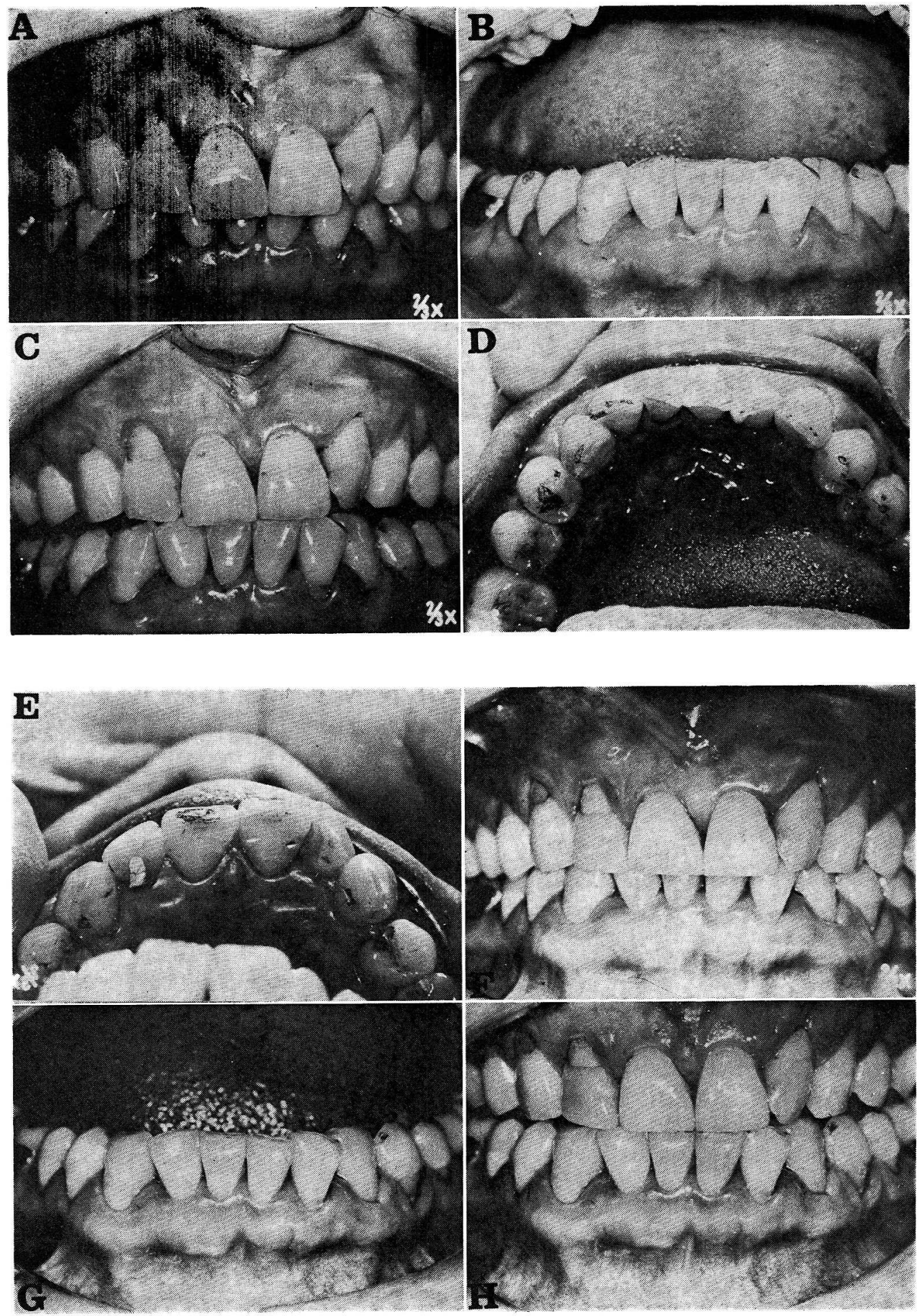


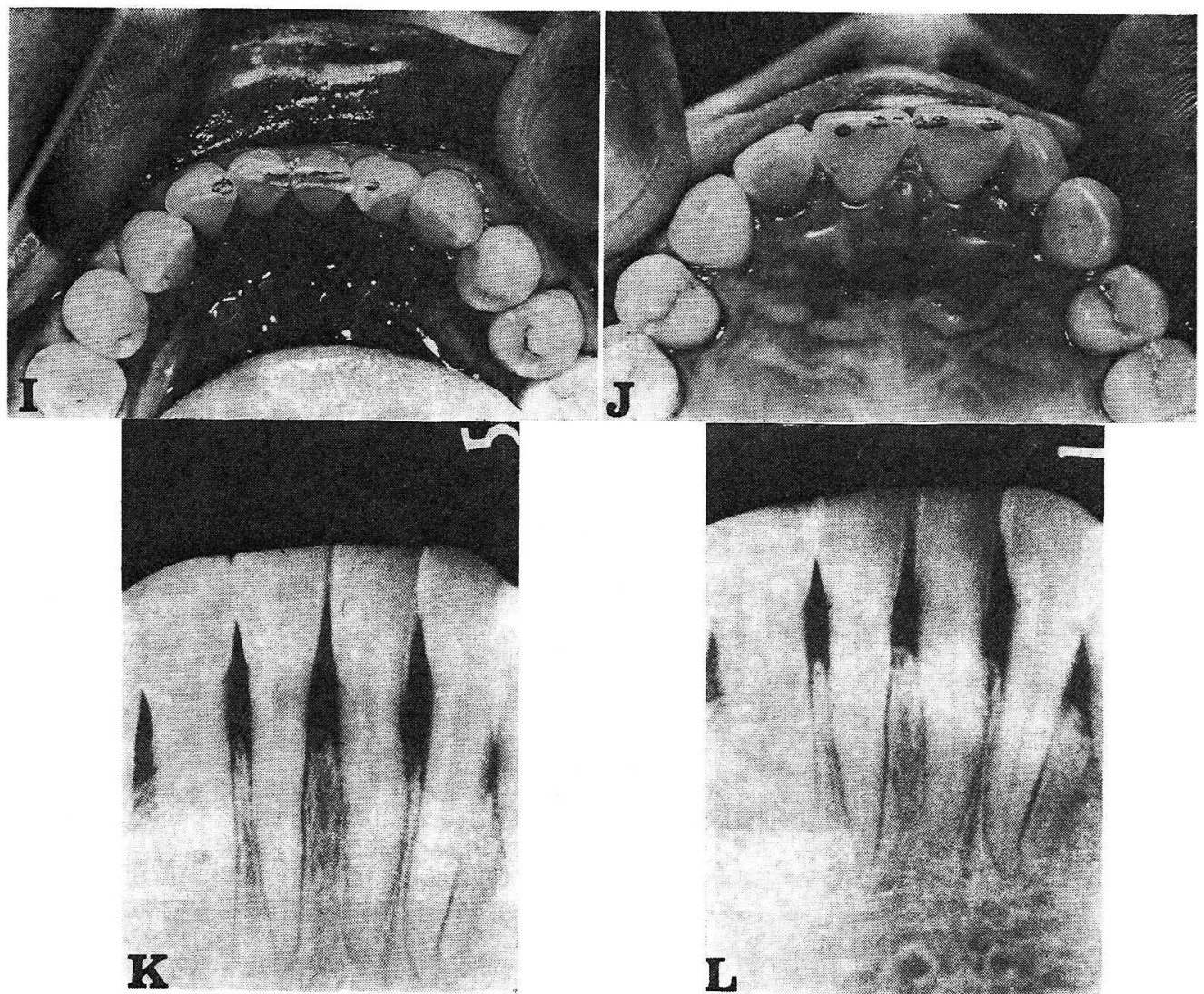

図 2 症例 2

A : 術前の咬頭嵌合位, やや哚いoverbite がみられる

B : $2--2$ の切端咬耗は強い

$\mathrm{C} \sim \mathrm{E}$ : 前方位において特に- $\frac{1}{21}$ の強い接触がみられる

$\mathrm{F}$ : 歯冠の形態修復 9 力月後の所見. 咬頭嵌合位にて overbite より overjet に変わる

$\mathrm{G} \sim \mathrm{J}$ : 前方位で $\frac{1}{2-2}$ は均一に接触している

$\mathrm{K}:$ 術前

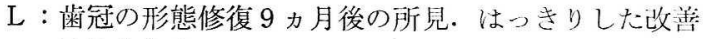
はみられない

係は overbite より over jet に変り, $\frac{1}{2-2}$ の切端水平 位は揃い, 前方位で均一に接触している。歯周ポケット は消失し, 歯の動摇は, はっきりと減少した。但しX線 学的に, はっきりした改善はみられない(図 $2-\mathrm{F} \sim \mathrm{L}$ )。

[症例 3] 34 歳, 女性, 部位: 44 咬合性外傷を伴 う 歯周炎

術前の所見：来院時 44 は急性菌周膿陽を呈し，同部位 の煩側歯肉に腫脹と排膿を認める。歯周ポケットは煩側 辺縁中央部で $4 \mathrm{~mm}$ のほか, 遠心側に向かって媣い。 咬合状態は，咬頭嵌合位における早期接触と側方運動 時，急な煩側咬頭による強い接触のため動摇がみられ
る。X線学的には菌根㓮囲に大きな㓌影がみられる。よ ってこの歯周膿瘍は, 咬合性外傷が原因で生じたものと 診断した。な拉歯髄の電気診でムはvital である(図 $3-\mathrm{A} \sim \mathrm{D})$ 。

治療経過ならじに予後：44の咬合性外傷を除去するこ とが急務と考え，まず歯冠の形態修復を行った。すなわ ち側方運動時にみられる 4 の煩側咬頭内斜面の強い接触 を削除しながら，主適な接触を得るよう，なだらかな咬 頭に修正した。その後，456 の範囲でフラップ手術を 行った。再度咬合調整を行い, 処置 1 年後の所見では, 㐘周ポケットは消失し, 歯の動摇は著しく軽減した。 $\mathrm{X}$ 


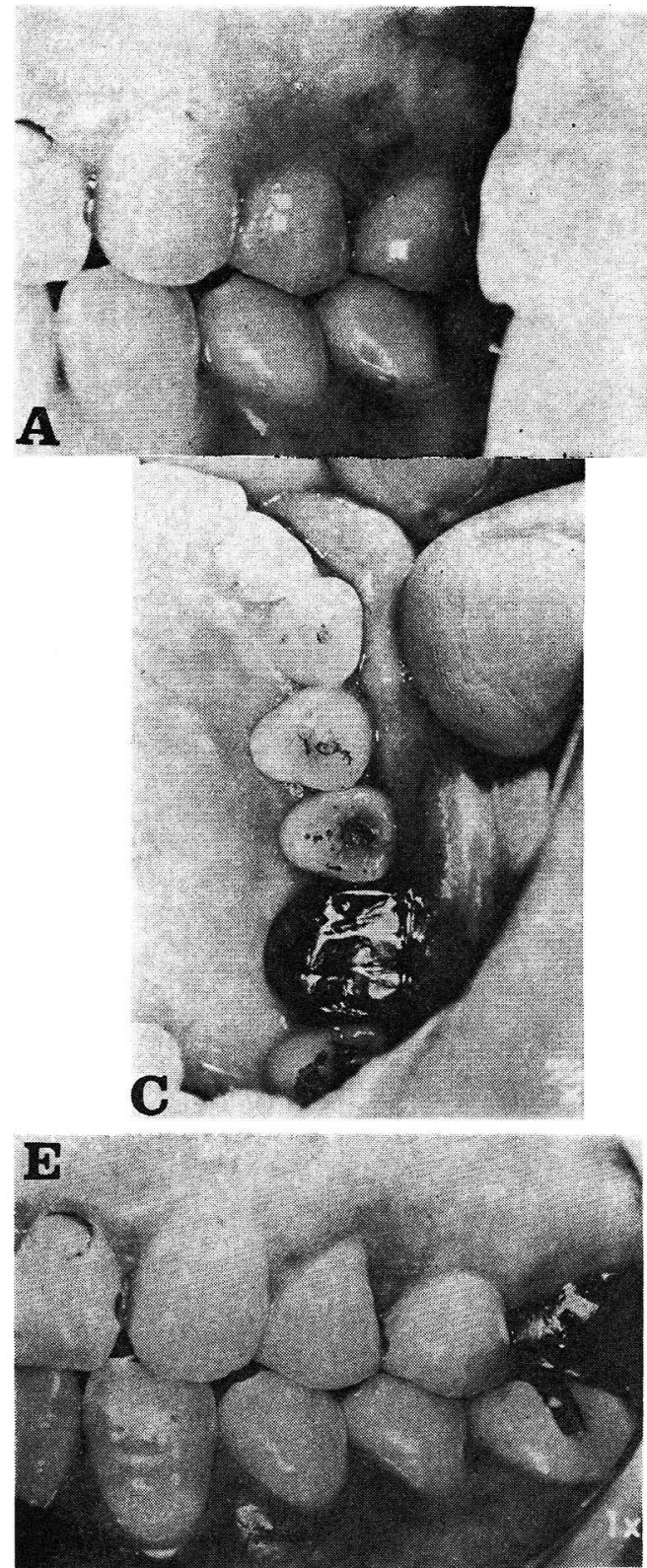

図 3 症例 3

A : 術前. 45 歯閒部に歯周膿瘍がみられる

B : 術前. 44歯根周囲に大きな陰影がみられる

$\mathrm{C}:$ 術前. 4 煩側咬頭内斜面に強い咬合印記がみら れる

D：術前. $\sqrt{4}$ の強い咬合印苔

$\mathrm{E}$ ：歯冠の形態修復後 1 年経過. 45 㡀䦌部は健康 歯肉にもどる

$\mathrm{F}$ : 歯冠の形態修復後 1 年経過. 44 の歯根周囲に著 しい骨の再生を認める
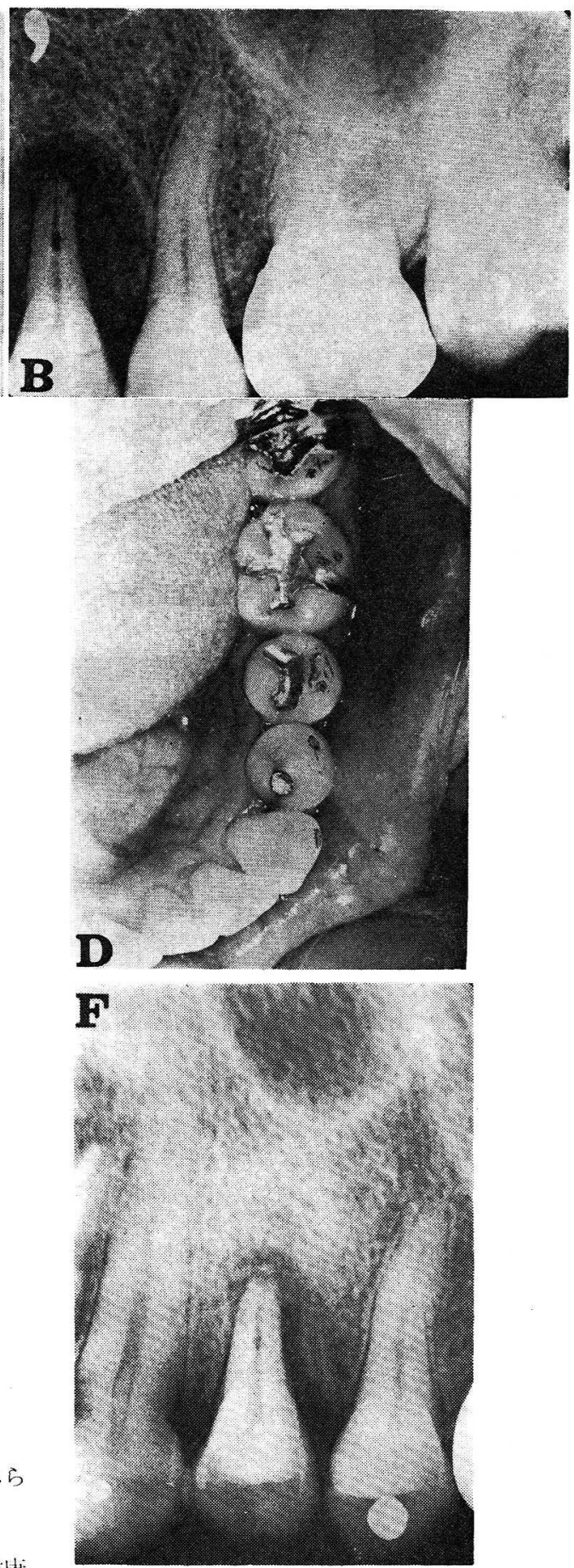

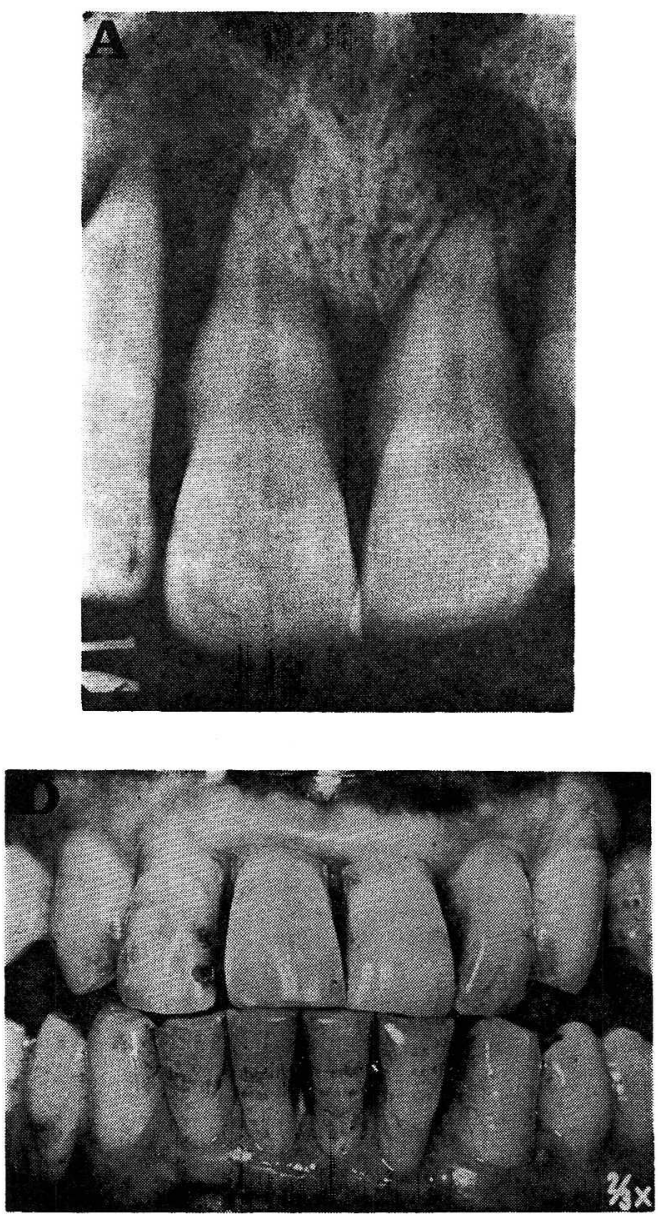

図 4 症例 4

A : 術前. 2 の歯根周囲に应範な骨吸収がみられる

$B$ : 歯冠の形態修復後 9 力月経過. 咬頭嵌合位で均 一な接触がみられる

C : 歯冠の形態修復後 9 力月経過. 切端水平位は, きれいに揃っている

D : 蒾冠の形態修復後 9 力月経過. 前方位で $2--2$ の $2-2$ との均一な接触がみられる

ほ : 歯冠の形態修復後 9 力月経過. 2 の歯根周囲に 著しい骨の再生がみられる

線学的に著しい骨の再生を認め，予後はきわわて良好で ある(図 3-E，F）。

[症例 4] 47 祡, 男性, 部位：21咬合性外傷を伴 歯周炎

術前の所見：21 において，歯肉の炎症はきわめて軽 いが，歯の動摇は著しく強い。歯周ポケットは歯間部で $5 \mathrm{~mm}$ と比較的深い。2 1 は前方位で，2瑐方滑走， 側方前方位で強い接触をしている。市きらかに两歯は咬
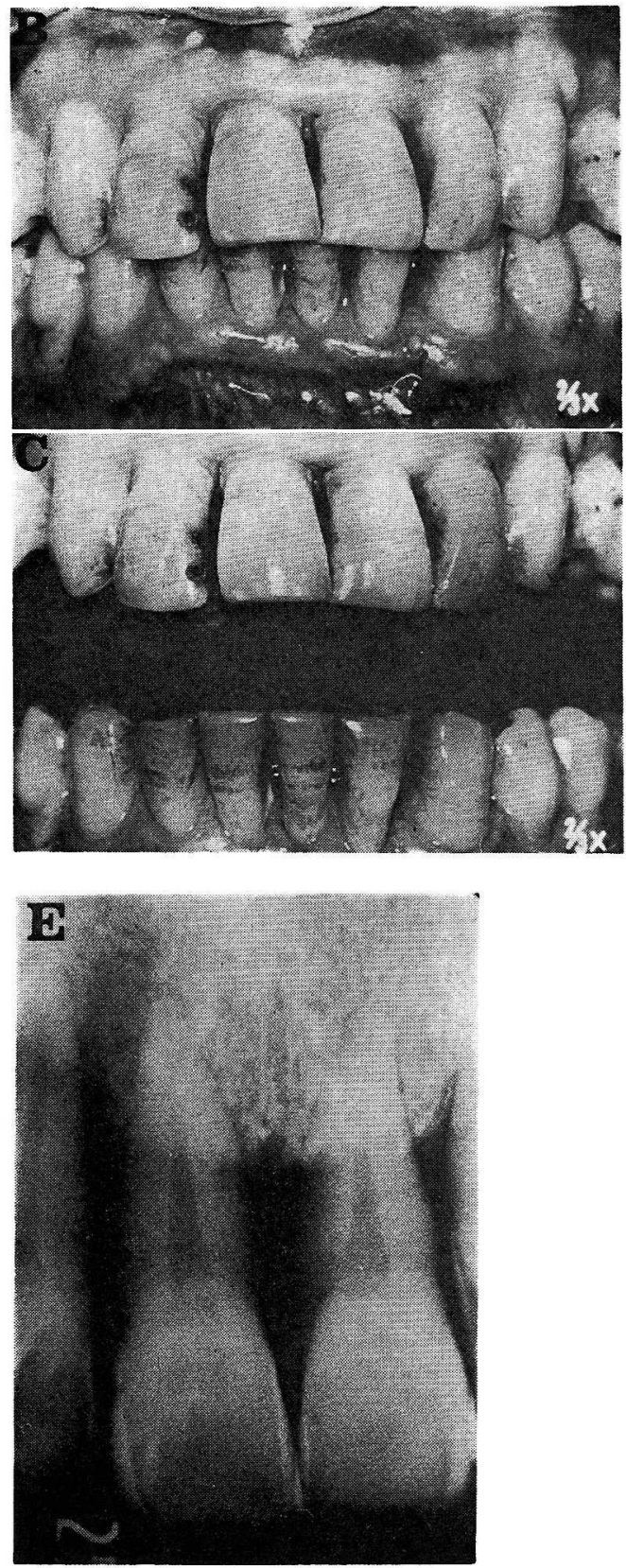

合性外傷に罹患している。X線学的に2は根尖部から公 範囲にわたり骨吸収がみられる（図 4-A）。

治療経過と予後：まず患歯を含めて全顎にわたり，プ ラークコントロールと歯石除去ならびに根西の滑沢化を 行った。ついで 21 を中心に $\frac{2-2}{2--2}$ の咬頭嵌合位, 前方 位, 同滑走, 側方前方位, 同滑走時での歯冠の形態修復を 行った。南周手術は一切行わなかった。処㽞後 9 力月経 

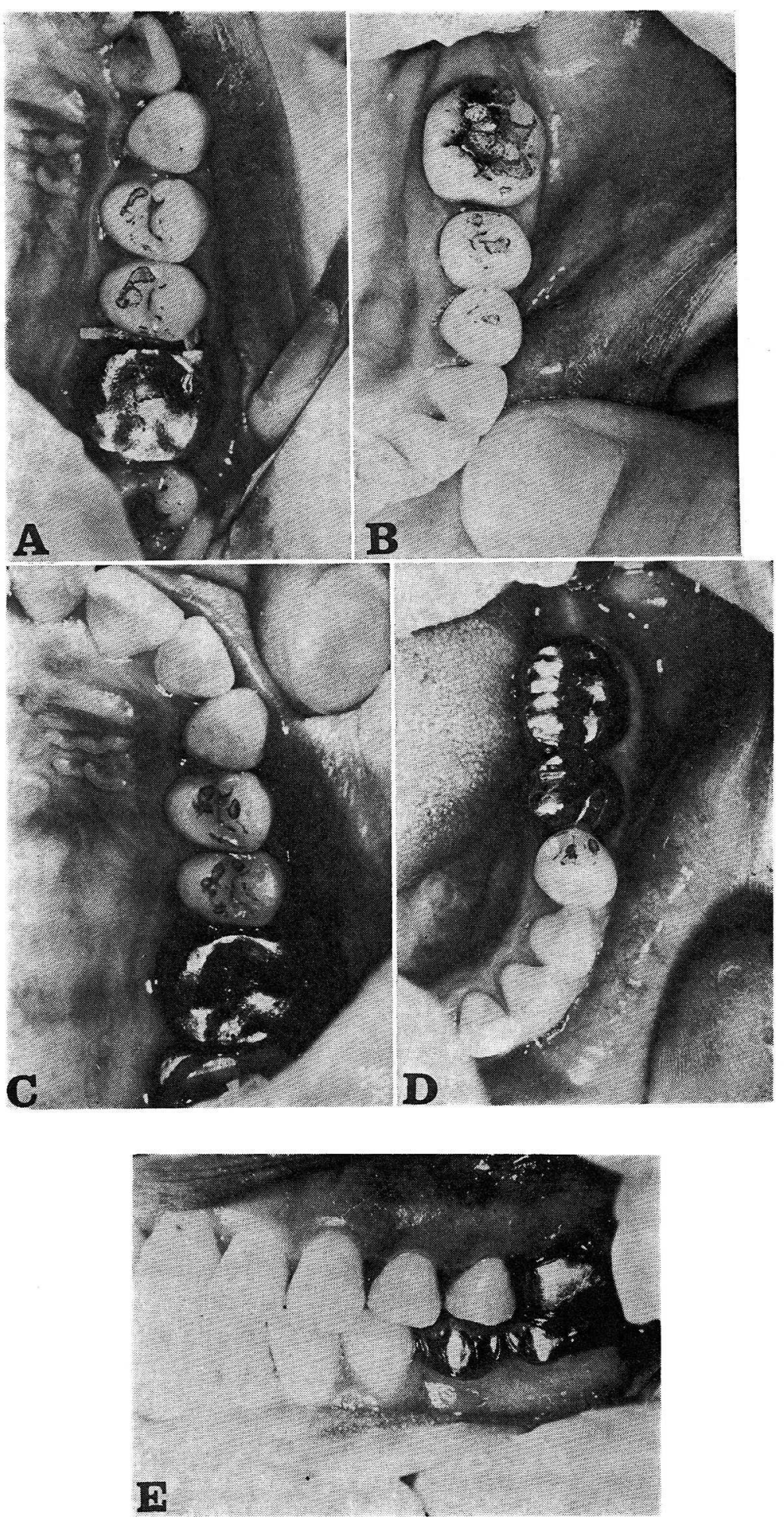


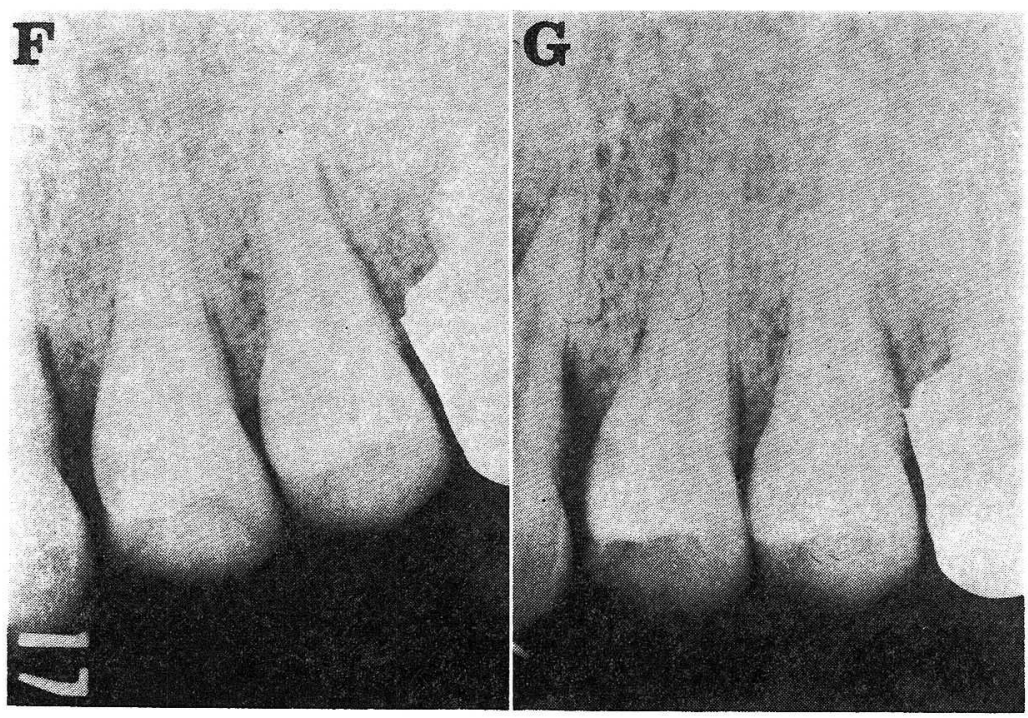

図 5 症例 5

A, B : 56 強く且つ面接触している

C：560咬合接触の修正. 6 の特に冠煩舌径の減少と近心辺 縁部の修正を行

$\mathrm{D}$ : 56 亿冠装着する

$\mathrm{E}: 56$ の側面からみた咬合関係

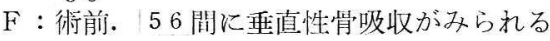

$\mathrm{G}$ : 歯冠の形態修復 11 力月後の所見. 肾の再生があきらか にみられる

過の所見では，料同ポケットは消失し歯の動摇も減少し た。X線学的に 2 の根尖部周囲にあきらかに骨の再生が みられ予後はきわぬて良好である(図 4-B〜E)。

[症例 5] 34 筬, 女性, 部位：56 咬合性外傷を伴 引歯周炎

術前の所胃： 56 は 56 と强く且つ面接触している。

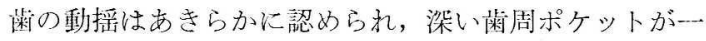
部5の舌側から迼心側にかけてみられる。X 線学的に 56 間に严㨁性骨吸収が認められる（図 5-A，B，F）。 治療経過ならびに子後：まずプラークコントロールと deep scaling を行ったあと画冠の形態修復を行った。 56 Kついては，う蝕のため抜髄を施し，ついで冠装着 した。 56 は面接触から点接触に修正, 同時に 6 冠の䫪 舌径の減少と近心辺縁部の修正を行った。歯冠の形態修 復後, 11 力月経過の所見において, 56 の歯周 ポケッ 卜は消失し，歯の動摇はあきらかに減少した。X線学似 に15の周囲及び 56 の蒾閒部に骨の再生がみられ, 経過 は良好である（図 5-C〜E，G）。

[症例 6] 30 歳, 男性, 郭位: 1]咬合性外傷を伴引
菓)咭炎

術前の所罗：17の挺出により咬頭嵌全位, 解少位時1 との強い接触がみられ，1てでは菌の強い動摇と舌側根周 用に著しい骨の吸収がみられる。歯楇ポケットは舌側部 で特に深い(図 6-A〜C, H)。

治療経過ならざに予後：治療第 1 期としてまず患料を 含わて全䞄にわたりプラークコントロールと歯石除亡な らびに根面の滑沢化を行った。ついで居中心に $\begin{aligned} & 2--2 \\ & 2--2\end{aligned}$ の咬頭嵌合位, 前方位, 前方滑走時での歯冠の形態修復 を行った。その後, 2-ー2 の範囲でフラップ手術を行っ た。処置後 8 力月経過の所見では, 歯周ポケットは消失 乙菊の動摇は著しく娍少した。X線学的に I,の根周囲 に, あきらかに骨の再生がみられた。子後はきわめて良 好である(図 6-D〜G，I）。

\section{考察}

疫学的に歯周病の発生, 進行を考えると, 30 歳代後 半から増加の傾向を示し，この年代から高度の葙周炎に 

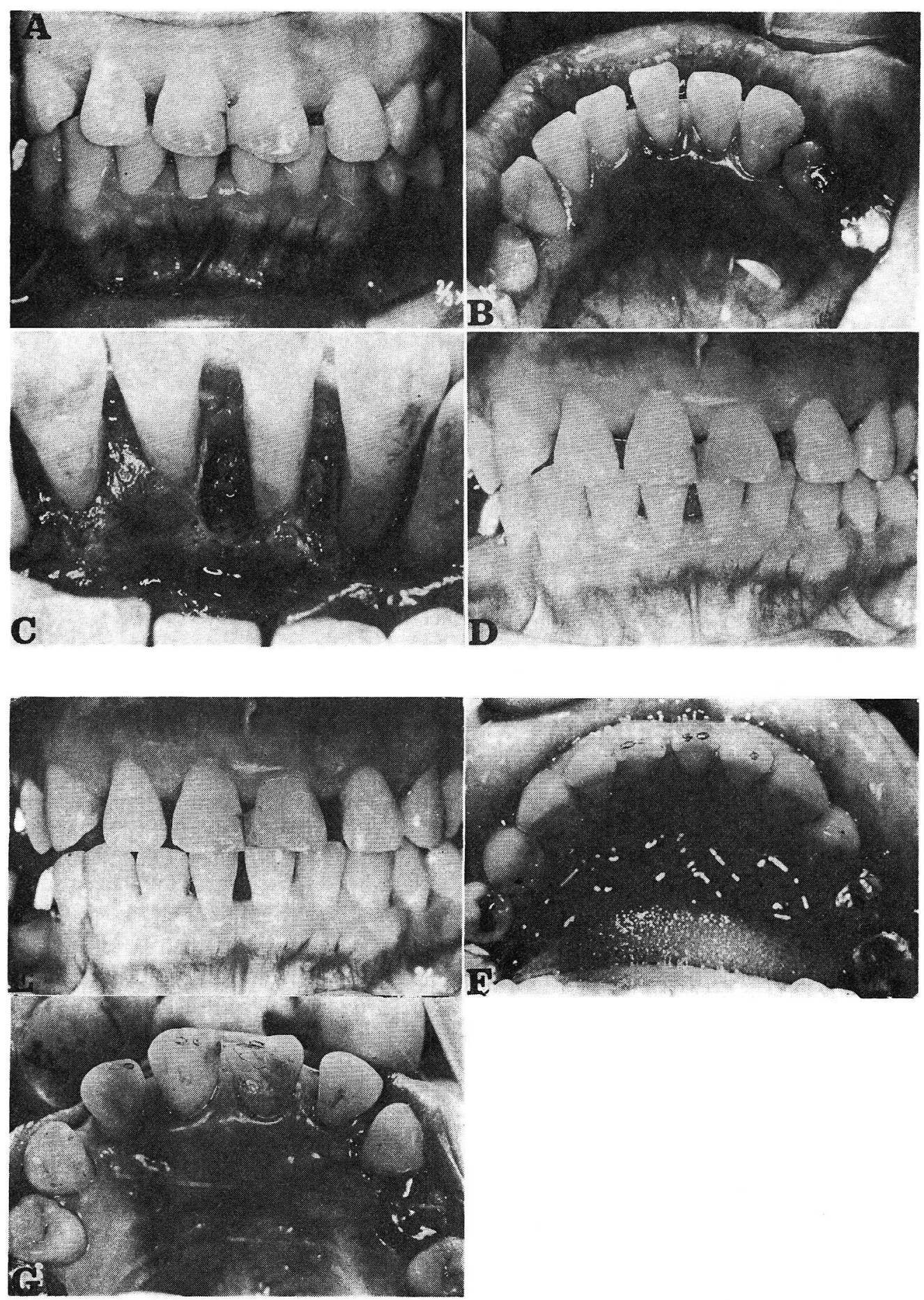


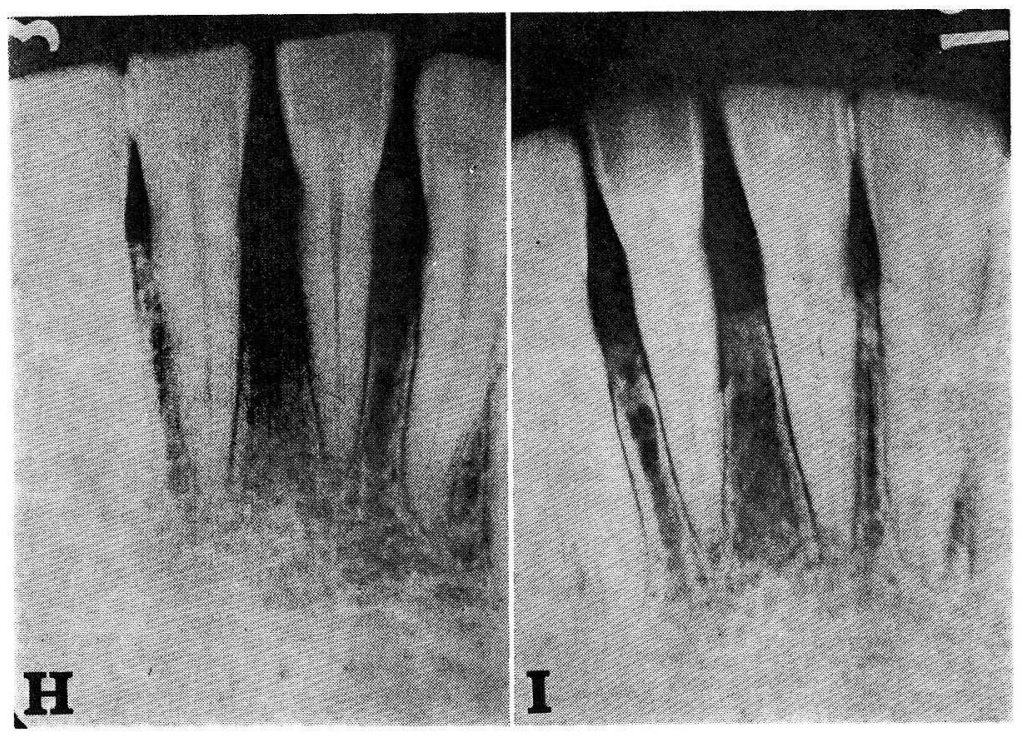

図 6 症例 6

A : 術前. 咬頭嵌合位での overbite

$\mathrm{B}$ : 術前. 1 の挺出

C : フラップ手術時. 1のの舌側根周囲に著しい骨の吸収がみられ る

$D$ ：歯冠の形態修復後 8 力月経過. 咬頭嵌合位でやや over jet $に$ 変わる

$\mathrm{E}$ ：歯冠の形態修復後 8 力月経過. 前方位で1!1の $1 \mid 1$ との均一 な接触がみられる

$F, G$ : 歯冠の形態修復後 8 力月経過. $\frac{1 \mid 1}{1 \mid 1}$ の均一な咬合印記

$\mathrm{H}$ : 術前. 1 门根周囲に骨の吸収がみられる

I : 歯冠の形態修復後 8 力月経過. 门の歯根周囲に骨の再生がみ られる

移行するまでに 20 年を要する7)。本研究は 30 歳代, 40 歳代の患者に咬合性外傷例が圧倒的に多いことを示し た。このことは，さきの疫学的デー夕と考え合わせてみ ると, 咬合性外傷は 30 歳代以後の歯周病の増龄的進行 に対して，何らかの役割を担っているように思われる。 本研究に求ける咬合性外傷歯の出現率は, 調查総歯数 1,011 歯中咬合性外傷歯は 140 歯の $13.8 \%$ と判明した。 このことは患者一人当り $2 \sim 3$ 歯は咬合性外傷歯に罹患 している割合となる。前歯部と臼歯部とでの咬合性外傷 歯の出現摔をみると, 前歯部の方が臼㐘部よりも多いこ とが垫められた。前桠部が多いことについては, 墚い咬 合関係にある上下前歯の前方位, 同滑走, 侧方前方位, 同滑走時に生ずる接触異常が帰因するのであろう。現に Ross $^{8)}$ は, 中等度な overjet であると前歯部の傷害は 少く, 一方 deep な overbite で overjet が少いと 前歯部はより傷害をうけやすいとのべている。このこと は, 深い咬合関倸にある上下前歯は咬合性外傷と密接な
関係を有することを示唆したものである。

また目歯部では全般的に下頡にくらべ上䫑の方に多発 する傾向がみられたが，これは Hirschfeld らが行った 長期の歯周治療の予後観察9 で示された歯種別罹患傾向 と一致する。この中で Hirschfeld らは上頻大臼歯を口 腔内に長く保存することは大変に難しいとのべている。

本研究は, 歯冠の形態修復後に咬み合わせが変化した と答えた者は 37 名中 17 名の $50 \%$ また歯ぎしりの習 癖を有した 8 名は, 歯冠の形態修復後に全員習癖がなく なったことを示した。石川ら ${ }^{10)}$ は，ブラキシズムの局所 的因子として咬合の不調和を考えている。実験的にヒ卜 の臼歯に高いインレーを装着したところ, 臨床的にブ ラキシズムを自覚し, 筋電図学的にも変化が認められ $た^{11)}$ 。早期接触歯に咬合調整を行うことで, 筋電図学的 飞咀嚼筋群の異常緊張が取り除かれるとのべている10, 12)。本研究結果と同じくRoss ${ }^{13)}$, Graf ら ${ }^{14)}$ はブラキシ ズムを有する患者に咬合調整を行ったところ，ブラキシ 
ズムが消失したことをのべている。

歯冠の形態修復の原則 8,15$)$ は, 側方力を垂直力に変更 する。上下前歯どうしの面接触を線または点接触とし， さらに接触位置は切縁寄りに変える。煩舌径を減少す る。面接触を点接触に変更する。一連の咬合接触とする。 突出咬頭や深い咬頭をなだらかにして摇れとか wedging を失くす。辺縁隆線を形成して, 垂直性食片压入を 防止するなどを考えている。本研究に打いて，8名のブ ラキシズム全員に効果がみられたことは，これら原則に そった咬合調整が 8 名全員に施されたものといえよう。

さらに Ross ${ }^{15)}$ は, 歯冠の形態修復の効果として, (1) 歯間離開が閉鎖する, (2) 1 歯ないし 2 歯の交又咬合は修 正される, (3) 頓舌側への転位歯が正常な位置にもどる などをあげている。本研究の症例報告の中で(1)に該当す るものは症例 1 で，(3は症例 6 がこれに該当する。

山内ら ${ }^{16)}$, 石川ら ${ }^{17)}$ は早期接触および平衡側接触を除 去することにより，顎関節症を治験した例を紹介してい る。また Posselt の報告 ${ }^{18)}$ では, 顎関節症患者 20 名に ついて咬合調整を行ったところ, やや治癒した範囲まで 含めると $95 \%$ と治癒率が高いことを示している。本研 究では, 術前, 顎関節部の疼痛および機能異常を有した 3 名のうち, 咬合調整後に 2 名が改善した。

咬合性外傷の臨床的徵候と症状のうち，代表的なもの は歯の動摇の増加, X線学的所見としては歯 根膜腔の 拡大, 歯槽硬線の消失, 歯槽骨の吸収などがあげられ る $^{3,5)}$ 。本研究は予後診査のためにこれらの 所見を採用 した。歯の動摇について, 上顎前歯では $6 \mathrm{~mm}$ 以上の overjet の場合に動摇歯がより多く出現するといわ れ ${ }^{19)}, 18$ 歳から 30 歳までの 17 名の女性の 363 歯につ いて咬合接触と動摇との関係をしらべた報告20)による 之, 咬頭嵌合位で咬合力が垂直性の場合, 動摇歯の出現 率は $6 \%$ に対して，咬合力が水平性の場合は $11 \%$ と増 加した。

従来から咬合性外傷と歯の動摇とは密接な関倸にあ る。加藤 ${ }^{21)}$ は, 咬合調整の効果を歯周組織の粘弾性の指 慗である共振振動数の変化でしらべ，この值が高くな り，正常值に近づくことを確認している。Vollmer ら ${ }^{22)}$ は, O'Leary 考案の動摇度测定器にて, 咬合調 整前後 の動摇度を測定したところ, 比較的早い時期に大幅な改 善が認められたとのべている。これらの報告は,いずれ も咬合調整によって歯の動摇が減少したことを示してい る。本研究の改善率は, 前歯, 臼歯ではそれぞれ 34.6 $\%, 61.2 \%$ となり, 前歯にくらべて臼歯の方があきらか に高いことを示した。しかも前歯，目歯ともに術前に動
摇の著しい外傷歯ほどより改善する傾向が認められた。 すでに著者ら ${ }^{4,6)}$ は, 深い咬頭斜面を有し，咬みこん でいる臼歯または平衡側咬頭干渉がみられる臼歯では㐘 周組織に無理な力が働き，傷害を起こすことが多いこと を報告している。本研究において, 鋭い咬頭斜面を有す る咬合性外傷歯 21 歯中 14 歯の咬頭を修正したところ, 約 $85 \%$ が改善した。このことから鋭い咬頭斜面を有す る咬合性外傷歯に対しては，できる限り，咬頭をなだら かにすべきである。

\section{総括ならびに結論}

1）年齞は 22 歳から 54 歳までの患者 37 名を対象と し, その総歯数 1,011 歯中咬合性外傷歯は 140 歯とな り, 咬合性外傷歯の出現率は $13.8 \%$ と判明した。

2）歯冠の形態修復後に歯ぎしり, 顎関節部の疼痛お よび機能異常の改善がみられた。また適正な位置に歯の 移動がみられた。

3）歯冠の形態修復後, 咬合性外傷歯の動摇は前歯, 臼歯ともに減少した。しかも前歯にくらべて臼歯の改善 率の方が有意に高く認められた。

4）歯冠の形態修復後, 歯槽頂, 白線, 歯根膜腔など X線学的所見の改善率は低かったように思われる。この ことは, 今回の調查期間が短かったためと考えられる。

5）歯冠の形態修復の予後に関しては, 咬合性外傷㐘 131 歯中良好 27 歯, やや良好 57 歯で両者を合わせると $64 \%$ 改善が認められた。

6）予後判定の基準として採用した，歯の動摇度なら びにX線学的所見は客観的評価としてやや乏しい感じは するが，今回の調査は咬合調整の効果を示す一つの目安 を与えたものと考えられる。

\section{文献}

1) Ross, I. F. : Occlusion-A concept for the clinician. C.V. Mosby Co., St. Louis, 1970.

2）池田克己，上羽隆夫，原 耕二共訳 : 歯周疾患の 咬合治療. 医歯薬出版, 東京, 1976.

3）中島 真, 山岸 茂, 原 耕二 : 咬合性外鹪と柬 冠の形態修復. 日歯周誌, $20: 98-105,1978$.

4）原 耕二, 中島 真, 山岸 茂 : 咬合性外傷之歯 冠の形態修復. 日本歯科評論, $426: 65-72,427$ : 57-65, 1978.

5）原 耕二：咬合性外傷の診断と咬合調整. 日歯医 
師会編, 新臨床歯科学講座 4 , 医歯薬出版, 東京, 1978, 104-118.

6）原 耕二, 中島 真：咬合性外傷と歯冠の形態修 復. 不川純編, イヤーブック 1979 歯周病学, ク インテッセンス出版, 東京, 1979, 151-164.

7) Carranza, F.A. : Glickmans' clinical periodontology. W.B. Saunders Co., Philadelphia • London, 1979, 319-351.

8) Ross, I.F. : Incisal guidance of natural teeth in adults. J. Prosthet. Dent., $31: 155-162$, 1974.

9) Hirschfeld, L. and Wasserman, B. : A longterm survey of tooth loss in 600 treated periodontal patients. J. Periodontol., 49 : 225237, 1978.

10）不川 純, 加藤 喣, 林 和彦：咬合の基礎的な 問題と咬合調整-6-. 菌界展望, $39: 683-692$, 1972.

11）伦藤文彦, 林 和楌, 任藤義広, 加藤 燳, 不川 純：早期接触の咀嚼系に及ぼす影響（第 1 報）。

日㐘周誌， $16 ： 321-327,1974$.

12）石川 純：咬合調整の効果と限界. 日歯周誌, 16 : 382-385, 1974.

13) Ross, I.F. : Coronal reshaping-A significant aspect of periodontal therapy. Ward, H.L. and Gardner, A.F. (eds.), A periodontal point of view, C.C. Thomas Publ., Springfield - Illinois, 1973, 53-67.

14) Graf, H. : Bruxism. Dent. Clin. North Am.,
$13: 659-665,1969$.

15) Ross, I.F. : Tooth movement and respositioning of the mandible without appliances. J. Prosthet. Dent., 31 : 290-296, 1974.

16）山内哲義, 榎阪 朗, 目 岩男, 中村公雄, 丸山 剛郎：咬合異常と狉関節症 その 1 咬合調整法に よる治験例．補経臨床， $8: 177-187,1975$.

17) Ishikawa, J., Katoh, H. and Satoh, F.: Effect of occlusal disharmony on masticatory sys. tem. Bull. Tokyo Med. Dent. Univ., 21 (Suppl.) : 107-114, 1974.

18) Posselt, U. : The temporomandibular joint syndrome and occlusion. J. Prosthet. Dent., $25:$ 432-438, 1971.

19) Wasserman, B.H., Geiger, A.M. and Turgeon, L.R. : Relationship of occlusion and periodontal disease Part VII -mobility. J. Periodontol., $44: 572-578,1973$.

20) Ross, I.F., D'Onofrio, E.D. and Roman, J.S. : Occlusal contacts and tooth mobility females, aged 18-30. J. Periodontol., $43: 760-$ $764,1972$.

21）加藤 憏：正常掞よび病的な歯周組織の共振振動 数の測定一歯周組織の生物学的診断の新しい方法 一. 口病誌, $35: 58-81,1968$.

22) Vollmer, W.H. and Rateitschak, K.H. : Influence of occlusal adjustment by grinding on gingivitis and mobility of traumatized teeth. J. Clin. Periodontol., 2 : 113-125, 1975. 